$2013 / 8$

\title{
The Impact of Urban Planning on the Development of Territorial Land Resources: Experience in Lithuania
}

\author{
Evaldas Ramanauskas, Liucijus Dringelis, Kaunas University of Technology
}

\begin{abstract}
This paper describes the planning situation in Lithuania after regaining the independence. All processes that have influence on planning process nowadays are the result of the evolution of legal basis, land restitution and economics conditions. Nowadays in Lithuania the planning process challenges many obstacles that are connected with private ownership, land restitution, land acquisition, as well as urban policy. The results of new urbanization are reviewed according to the following three aspects: economic, social and environmental ones. The paper discusses such rising problems as extensive suburbanization, random planning composition, as well as devoting special attention to organizational problems.
\end{abstract}

Keywords - Land use, master plans, territorial land resources, territorial planning.

Development of territorial land resources is one of the main measures for country social, ecological, economic well-being. It has an impact on urban functionality, rational land use, landscape attractiveness. In this paper, the territorial land development is understood as a certain strategy of land use, which combines main politics for land use and its territorial arrangement.

Such main factors of territorial land development can be distinguished as urban regulation, control and politics on territorial planning. These factors are very important for combining private and public interest, short- and long-term economic effect or other aspects.

In Lithuania, during the period of economic change urban regulation became very weak. The main reasons for this can be considered land reform, inspiration of market economics and absence of traditions in urban work with private property. The absence of urban regulation exerted a greater influence of planning factors, such as private interests, quick economic effect. Thus, it became more difficult to arouse public interest and ensure the long-term economic effect. In such a planning environment, there are often preconditions for scattered housing, overbuilding of valuable nature landscape places, destruction of continuous agrarian areas, etc.

This question is discussed among architect planners. Problems on urban planning are analysed in their practical and research work. The works of D. Bardauskienè, M. Pakalnis, P Aleknavičius, and others can be mentioned. The main aim of this paper is to show the experience of Lithuania in urban planning and its legal preconditions.

\section{The Formation of Legal Basis for Territorial Planning}

There are several laws that regulate the process of territorial planning in Lithuania: Law on Territorial Planning, Law on Land, Law on Land Reform, Law on Territories of Preservation, Law on Roads, Law on Green structure, Rules for Master Plan Preparation for Territories of Towns, Townships, Municipalities and others. Moreover, the Strategy on Sustainable Development is adopted on the basis of international documents of sustainable development.

As one important measure for urban planning is international agreements on sustainable development, whose environmental, social and economic principles have the legal effect in lot of countries. Many countries have approved the agreements of sustainable development and involved or try to involve its principles into their own legal systems.

In many countries, there are special laws on planning development that aim at achieving higher quality of space for living, work and rest [1]. However, according to the example of Lithuania, it can be said that although the strategy of sustainable development has been adopted, it still does not work as it should. Although a more powerful urban government is maintained, contrary processions occur in Lithuania.

The main principles of sustainable development are introduced into the objectives of Law on Territorial Planning, which is the main legal document of spatial planning. The main objectives of territorial planning are:

- to form usage, regulation and preservation conception;

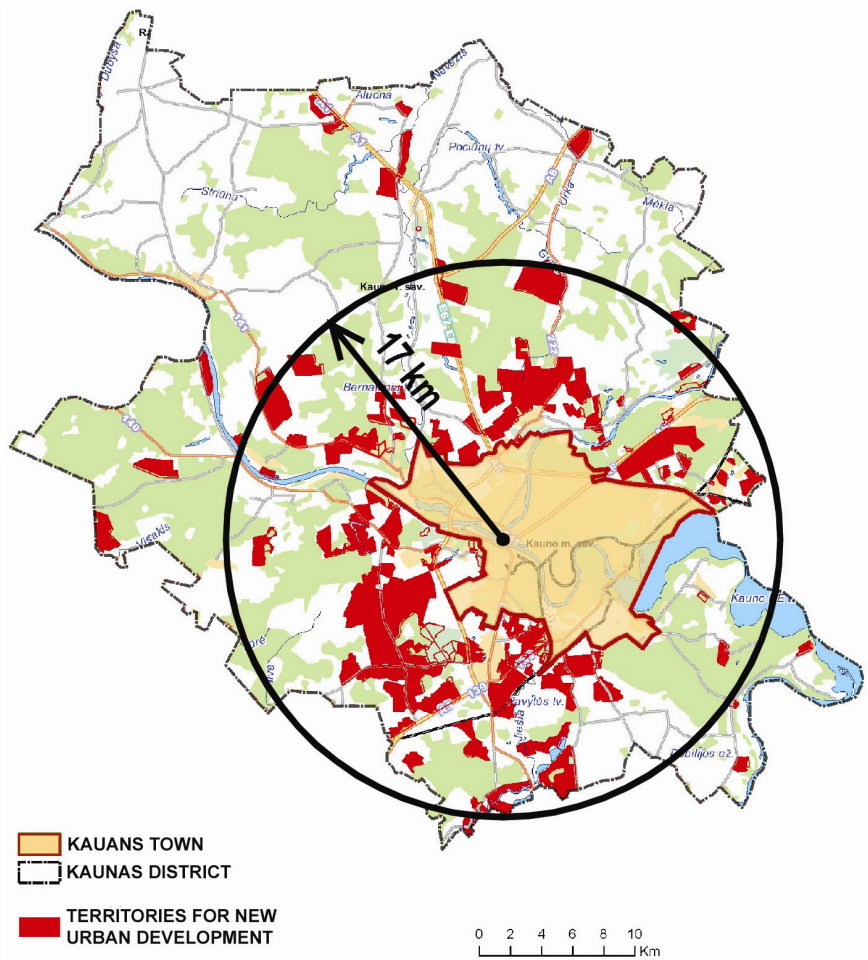

Fig. 1. Urban development in Kaunas district in the period of 2004-2011 according to the master plan of Kaunas district (2007). The balance of urban area in the circle of $17 \mathrm{~km}$ radius from Kaunas centre is: the existing urban area approx. $120 \mathrm{~km}^{2}$, a newly designed urban area- approx. $130 \mathrm{~km}^{2}$. 
- to balance urban and engineering structure;

- to determine measures for rational use and restoration of natural resources; development of natural frame; the preservation of cultural heritage of ecological systems;

- to determine measures for urban structure improvement, the system of green structure development;

- to reserve territories for public interest, infrastructure use and social use;

- others.

These principles represent the sustainable development, but their statements often are not implemented in practice. The main important question still remains - what should be done to achieve these objectives.

After the Soviet period, Lithuania experienced several periods of quite different directions of urban planning. The main factor of changing of territorial planning was land privatisation despite the solutions of planning documents that were in force. There was a series of amendments adopted to the laws that regulated the land restitution. More radical first steps were undertaken in 1997 when land reserved for town development was started to be privatised. From the very beginning, there was such an exception that the Law on Land Reforms stated that one could restitute only the land, which was near existing buildings that remained during the period of occupation (since 1940). However, this situation continued till 2002. Since 2002 non-regulated privatisation has started. Then all lands that were not occupied by existing buildings, streets could be restituted or just privatised for compensation of other lost land in other places. Thus, such land privatisation regardless of master plans led to a chaotic structure of new boundaries of land plots and to the lack of territory reserve that was needed for public interest (transport system development, social infrastructure, green space creation, recreation zone broadening).

It is very important to mention that new boundaries of plots occupied river banks, river slopes, sometimes they appeared in park areas and so on. Therefore, it was mostly a politic procedure, which created new conditions for territorial planning. All earlier adopted planning documents became almost useless, especially it concerned green areas, parks, recreation zones. Although in such territories all new land parcels were designed for an agrarian land purpose (that was the condition for land restitution), it arouse private owners' interest to develop that land as urban territories despite public interest.

There was not any established order to expropriate that land, which was designed for public purposes. Therefore, further planning process became very indefinite.

Old planning documents became not suitable for new interest caused by land privatisation. Thus, new planning documents were needed. Taking into consideration the fact that development of territories could not be stopped even if there were no new main planning documents, master plans were needed to prepare special and detail plans not considering the hierarchy of planning documents. Therefore, new detail and special plans were prepared initiated by private owners in very different places; it was impossible to resolve the issues of common engineering, transport infrastructure, and social wellbeing. As many projects were prepared for a very small territory - one parcel, they often caused preconditions to form chaotic urban composition.
Together with local planning process (detail, special planning), a little bit later new master plans were also developed. A majority of new territorial documents were prepared in the period of 2005-2011 mainly supported by the European Union; the process is underway nowadays.

First of all, as master plans are organised by municipality, financed mainly by the EU, they should solve all problems that are not coherent with sustainable development. However, in reality when there are very contrary and indefinite factors for planning often planning proposal appear that cannot be appraised in favour of sustainable development.

\section{The Experience of Urban Planning In Lithuania}

It is natural that each person is willing to have his / her own individual house, live near the nature, river or other amazing view. Therefore, a lot of land owners started to achieve such living conditions for themselves or for better business. Hence, a new building area for living, new area for commercial use have become one of the main economic arguments for new planning proposals. Analysing Lithuanian master plans it can be said that such arguments have great influence on their proposals.

As one very evident example, planning proposals of Kaunas district and Kaunas city can be shown. In new master plans of Kaunas city (2003) and Kaunas district (2008), territories were designed and fixed (from earlier planning proposals of detail and special plans) that are as twice bigger as the existing overbuilt area (Figure 1). As a result, such a big number of new areas that received permission for overbuilt can enlarge the territory of Kaunas .

To evaluate the impact of new urban procedures, it is important to take into account a general demographic situation, which should be the main factor of urban development quantity. In recent years, in Kaunas city and Kaunas district the population has decreased (Figure 2, Table I). The proposals of master plans do not take into consideration the demographic situation. The fact that population is increasing in Kaunas district can be explained by new suburbanization, which, of course, is designed in the master plan of Kaunas district. According to preconditions for new urbanization and forecast of population, only part of new urban structures can appear that all together will form a very low density of settling. This, of course, can have very big economic expenditure for streets, utilities, engineering infrastructure; therefore, new separate settlements can require new social infrastructure. Moreover, the impact can be exerted on environmental protection. In general, great economic, social, environmental effects can appear in the whole urban area. Thus, the main impact, according to each aspect, can cause new possible urban conditions:

- From the economic point of view, it can be mentioned that new living areas spread in a big territory do not have a common engineering infrastructure - there is no common sewerage, water supply, rainfall equipment and so on. To create infrastructure in a distant living group is much more expensive than in a more compact territory. Moreover, it is not beneficial to develop public transport because living density is very low. Of course, such a broad distribution of new living places causes a bigger distance from living 


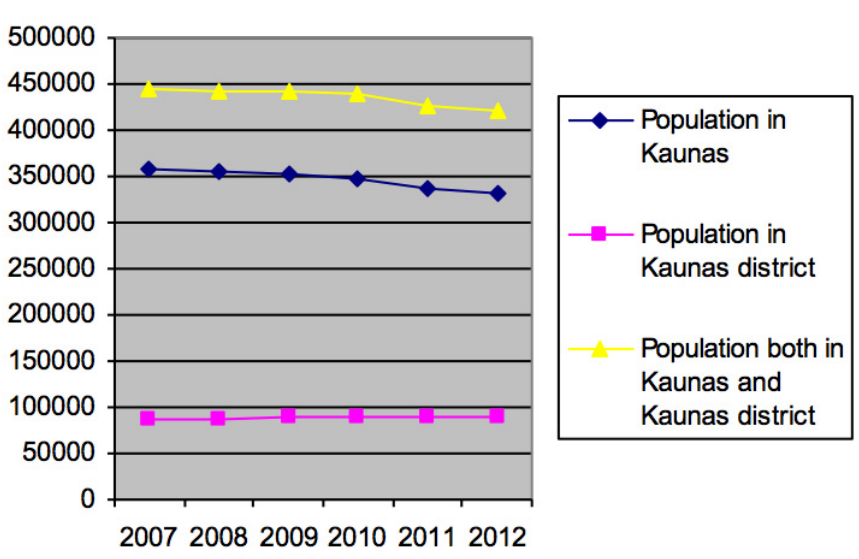

Fig. 2. The tendency of population change since 2005.

TABLE I

Population Change in Kaunas City and Kaunas District (Chronicle of Lithuanian Statistics, 2012).

\begin{tabular}{|l|l|l|l|l|l|l|}
\hline & $\mathbf{2 0 0 7}$ & $\mathbf{2 0 0 8}$ & $\mathbf{2 0 0 9}$ & $\mathbf{2 0 1 0}$ & $\mathbf{2 0 1 1}$ & $\mathbf{2 0 1 2}$ \\
\hline Kaunas & 358111 & 355586 & 352279 & 348624 & 336912 & 330742 \\
\hline $\begin{array}{l}\text { Kaunas } \\
\text { district }\end{array}$ & 85721 & 86701 & 88666 & 90196 & 89262 & 89540 \\
\hline In total: & 443832 & 442287 & 440945 & 438820 & 426174 & 420282 \\
\hline
\end{tabular}

places and working places, and it is a precondition for increasing transport traffic and so on.

- From the social point of view, it is important to notice that in new broadly spread urban areas there is not social infrastructure: schools, children gardens, squares, parks (the surrounding open space is private - agrarian land!). Thus, without this infrastructure it is very difficult to form new communities.

- From the environmental point of view, it can be said that such non-regulated urbanization very often occupies the territories near lakes, rivers, slopes. Such urbanization causes the break of functional connections for fauna, as well for inhabitants of new communities.

Hence, such planning conditions do not create a good environment for new living, recreational and working area. Though these new areas are developed for better living quality, they do not have the areas of uniting these places into one full

TABLE II

Preconditions for Built-up Area according to Master Plans of Kaunas District (2008) and Kaunas City (2003) and Projections of Territory Density if Population does not Change.

\begin{tabular}{|c|c|c|c|}
\hline Year & $\begin{array}{c}\text { Built-up area in 17 } \\
\text { km radius } \\
\text { (Figure 1), km² }\end{array}$ & Population & $\begin{array}{c}\text { Density (persons/ } \\
\text { urban territory km² }\end{array}$ \\
\hline 2010 & $\sim 120$ & 420282 & $\sim 36$ \\
\hline 2020 & $\begin{array}{c}\text { Preconditions } \\
\sim 250\end{array}$ & $\begin{array}{c}\text { Projections } \\
\sim 420000\end{array}$ & $\sim 17$ \\
\hline
\end{tabular}

urban unit, one community. These areas are formed just for separate living, without any common areas, public spaces. The agrarian territories become surrounding with new urban areas that do not have any relation with agrarian development. In general, these areas still do not represent sustainable development - all occupied areas have not created space for general well-being.

According to such tendencies, new master plans were prepared to make more possibilities for really accident investments. Thus, territorial planning procedure started to serve for "non-planning" and more "prognostic" urban processes.

Newly created private land property caused new compositions of the plans of quarters, new groups of parcels for building. A lot of territories planned by individual land owners seem to be created more for present commercial needs, but not for the future welfare. A lot of territories are scattered far away from compact urban places in a chaotic way (Figure 3). As new areas of urban development mainly are overbuilt by single-family houses, they form one urban morfostructure. When this urban structure becomes very big as one unit, it creates the impression of a hypertrophic structure: without accents, without subdivisions of open space. According to the theoretical basis of K. Lynch, such structures become without any landmarks. Thus, a great area of new quarters becomes not identified as a unique place. Such a tendency is seen in the suburban area of all largest cities of Lithuania (Figure 4).

It can be said that it is very difficult to form a more valuable composition, as land is usually being planned in a small place, leading by the interest of individual private owners. Open spaces, accents (as higher buildings, squares) require greater regulation that should be the objective of governance structures. Present urban measures usually do not form more attractive composition; this only is done by measures of architecture, but this has an impact mainly on the scale of street, group of several buildings. The chaotic urban structures stand out by extensiveness, landscape fragmentation, lack of open and public spaces. Generally, they lead to monotony, loss of identity and attractiveness.

This cannot be shown as a total process. There are cases, when a big territory is developed by one project - one investor. In these cases, an urban structure is better, because usually minimal places of greenery, sports grounds are equipped. However, there are more exceptions than results of territorial planning system.

\section{The Directions for Improvement of Territorial Planning SYSTEM}

Territorial development without urban politics and regulation cannot correspond with the objectives of sustainable development that is adopted in the National Strategy of Sustainable Development, in the Law on Territorial Planning and other legal documents. Without urban politics, the present urban planning proposals are adopted in a very complicated way. The decisions are adopted during a planning procedure, which involves a planning organizer, the author of a plan, private owners, society, establishments of environmental protection, transport system and others.

In a theoretical way, the main author of a planning document is a planner, who creates the whole structure as it is required by prospectic urban ideas of higher living quality: street network, 

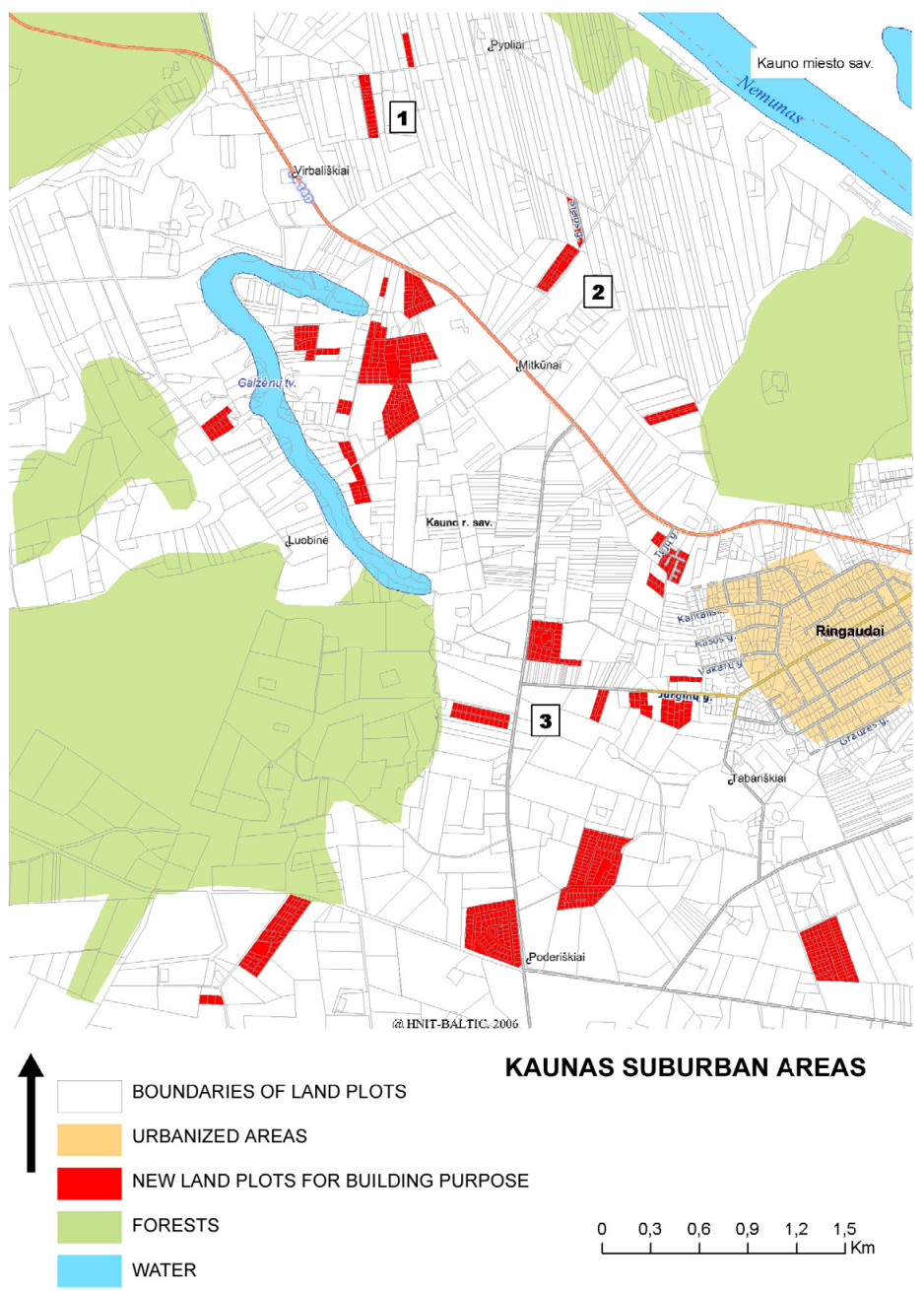
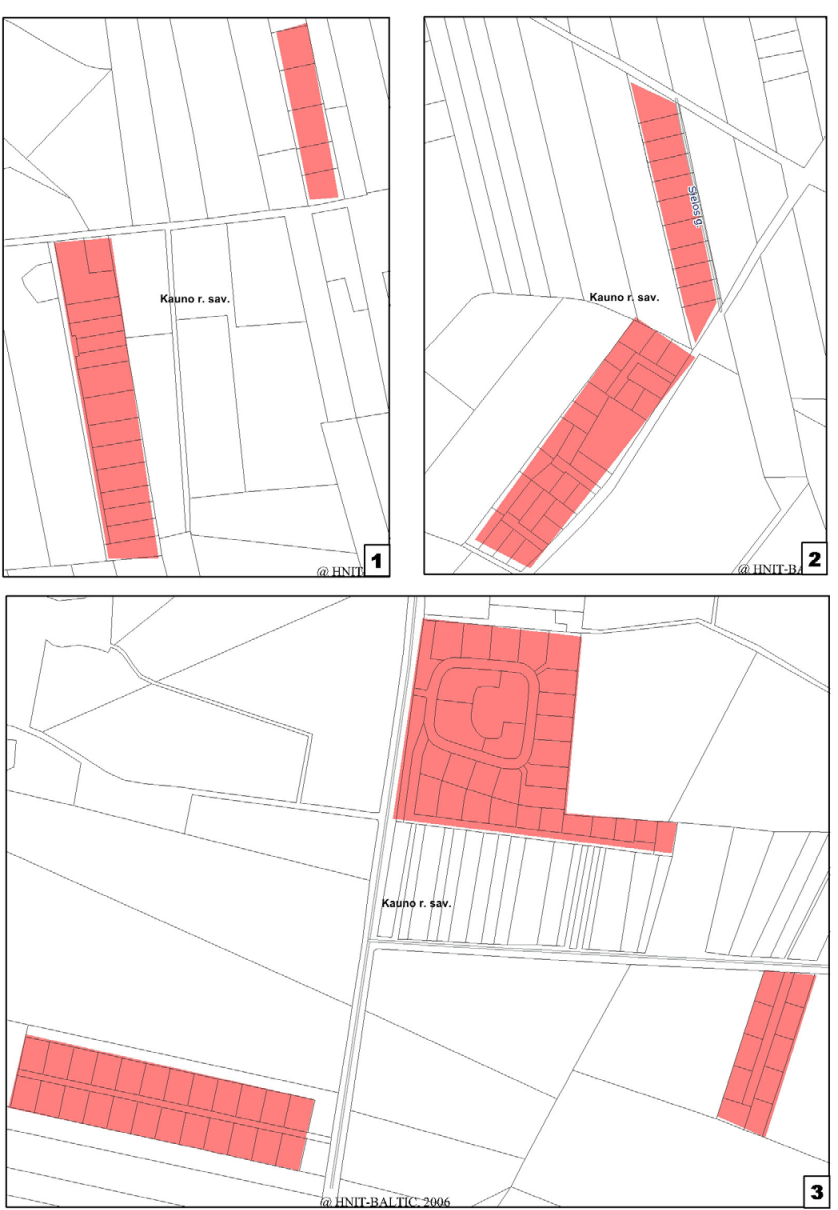

EXAMPLES OF NEW BUILDING PLOTS STRUCTURE

Fig. 3. The structure of new building plots for dwelling houses in suburban areas of Kaunas (in Kaunas district).

greenery system, urban structure, places for sport and so on. Of course, the proposals are considered by special government establishments, but as there is absence of consecutive planning laws, a lot of proposals of better living quality cannot be ensured.

In areas, where special establishments cannot ensure the need of living space quality, there is a great influence of private owners, who are seeking to increase their land value. The planning organizer, as the representative of authorities, often tries to satisfy most complaints. Usually there is not any comfortable street network, park system, sport facilities in the places they fit the best, or they are not included in a plan and so on. Nevertheless, these urban elements are needed for people, who live in that area or are going to live - local society, this argument still does not have power against individual private owners' rights. In this place, the society is often very weak. The weakness of society results in the fact that most of land is private and its acquirement for public use is not defined. There is not any order, which could define the right compensation for loss of land value, loss of landscape attractiveness, loss of agrarian land.

It should also be mentioned that land acquiring proceeds on mostly important things - streets, engineering infrastructure. There is also dissatisfaction of these owners, whose land is acquired by paying a low value in accordance with neighbouring parcels whose value rises very high, thanks to land that was acquired, for example, for a street.

Thus, such a procedure without a general urban regulation often causes irrational planning solutions. Certain similarities of such urban development, also called "urban sprawl", have occurred much earlier in the USA, Portugal, Germany and other countries. In order to fight with such problems, there are proposals to solve these problems, like smart growth, sustainable urbanism and others. In order to implement progressive urban proposals, a few countries solve problems by the use of land readjustment.

The present situation in Lithuania shows a very problematic territorial planning process that mainly causes the loss of territorial resources and not very rational new urban structures. The planning process is underway, but a real value of territorial land resources is not evaluated. In order to manage such a process, it is necessary to adopt new rules for planning urban areas, new norms that could regulate the interest of private persons and society. Moreover, there should be a strong institution, which could regulate all urban proposals in all territories, could monitor urban quality and rational land use. 


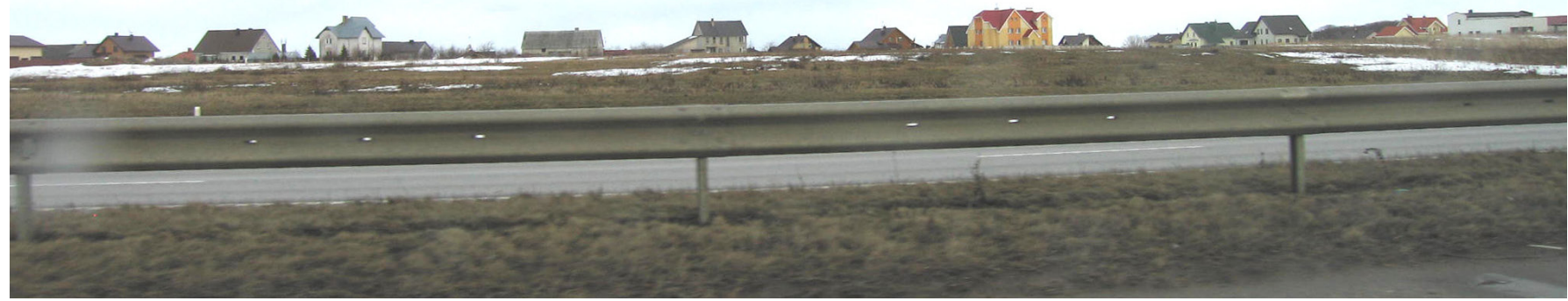

Fig. 4. The view of new building plots for dwelling houses in suburban areas of Klaipeda, as seen from a driving car (Klaipeda district).

\section{CONCLUSIONS}

1. Territorial land resources are one of the most important treasures in the world, whose rational use should be one of the main objectives of all countries.

2. Nowadays in Lithuania the planning procedure causes preconditions for a chaotic spatial structure of towns, their suburbs, rural areas because in planning documents a lot of new urban areas are designed.

3. Development of new urban areas creates scattered living quarters without public spaces, social infrastructure, and public transport service.

4. Main principles of sustainable development cannot be implemented because of a very complicated planning procedure and lack of regulation of urban quality.

5. The main measures for improvement of territorial planning system could be the establishment of a new institution of urban quality preservation, strict urban politics, new urban rules and norms regulating private and public interest.

\section{REFERENCES}

1. Aleknavičius, $\mathbf{P}$. Ar reguliuosime žemès ūkio paskirties žemès rinką? (Will it be regulated land market?), Žemes ükis, 2002, No. 1, p. 5-7.

2. Aleknavičius, P., Aleknavičius, M. Rational Land Use Planning when Preparing Master Plans of Administrative Territories. LŽUU mokslo darbai, 2010, No. 86 (39), p. 37-45. ISSN 1648-116X

3. Dringelis, L., Ramanauskas, E., Gudzinevičiùtè, G. The Use of Land in Master Plans of Towns from the Point of View of Sustainable Development. Environmental Research, Engineering and Management. Kaunas, 2011, No. 4 (58), p. 65-73.

4. Urban sprawl in Europe : The ignored challenge. European Environment Agency Report, 2006, No. 10.

5. Amado, M. P., Ribeiro, R. Urban Sprawl promoted through Master Planning [online]. Research Centre of Finland 2011, Konferenz: SB11 Helsinki World Sustainable Building Conference [cited 19.06.2012]. http:// www.irb.fhg.de/bauforschung/baufolit.jsp?s=planning+and+development $\& p g=6 \&$ wo $=$ cib $\&$ local $=$ de

6. Bardauskiené, D., Pakalnis, M. Current trends and management of urban development in Lithuania : reviewed paper. Real Corp 2011: 16th International Conference on Urban Planning, Regional Development and Information Society, May 18-20, 2011. Essen: Competence Center of Urban and Regional Planning, 2011, p. 139-144. ISBN 9783950311013
7. Muller-Jokel, R. Land Readjustment-A Win-Win-Strategy for Sustainable Urban Development [online]. Intercontinental Athenaeum Athens, Athens, Greece, May 22-27, 2004 [cited 2011-08-19]. https://www.fig.net/pub/ athens/programme.htm

8. Master plan of Kaunas district. MI „Kauno planas“, 2008 [online]. Kaunas municipality [cited 19.06.2012]. http://www.krs.lt

9. Master plan of Kaunas town. MI „Kauno planas“, 2003 [online]. Kaunas municipality [cited 19.06.2012]. http://www.krs.lt

10. Republic of Lithuania Law on Territorial Planning. 1995, No I-1120 [online]. Lietuvos Respublikos Seimas [cited 19.06.2012]. http://www3.lrs. lt/pls/inter3/dokpaieska.showdoc_1?p_id=343407

11. Schroepfer, T., Hee, L. Sustainable Urbanism: Ideals, Ideas, and Implementation in Vauban [online]. CCIM2006 Sustainable Development through Culture and Innovation, 26-29 November 2006, Dubai, UAE [cited 19.06.2012]. http://www.irbnet.de/daten/iconda/CIB4417.pdf

12. Lietuvos statistikos metraštis, 2012 (Chronicle of Lithuanian Statistics, 2012) [online]. Lietuvos statistikos departamentas [cited 19.06.2012]. http://www.stat.gov.lt/lt/pages/view/?id=2466

13. LR Piliečių nuosavybès teisių i išlikusị nekilnojamąji turtą atkūrimo istatymas (Law of restitution of remained property of Citizens of Republic of Lithuania). Žin., 1997, Nr. 90-2256.

14. Nacionaline darnaus vystymosi strategija (National Strategy of Sustainable Development). Žin., 2003, Nr. 89-4029.

15. Lietuvos Respublikos Žemès įstatymas (Republic of Lithuania Land Law). Žin., 2004, Nr. 28-868. 


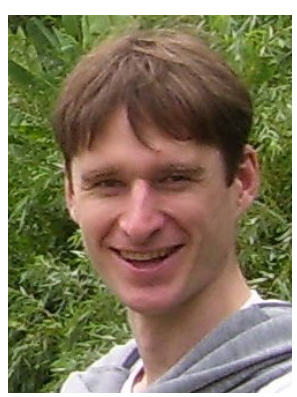

Evaldas Ramanauskas, Doctor of Humanities (2011) (Arch.) - Junior Researcher and Head of the Centre for Territorial Planning, (Kaunas University of Technology, Institute of Architecture and Construction)

Main research areas: effectiveness of planning documents, rational use of land resources, public areas, town and country landscape, open space, land management.

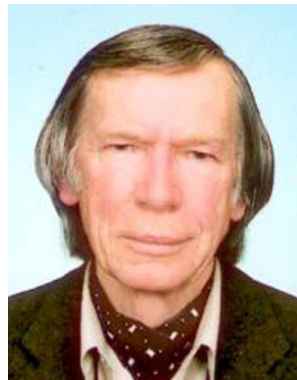

Liucijus Dringelis, Doctor of Humanities (1983) (Arch.) - Senior Researcher at the Centre for Territorial Planning, (Kaunas University of Technology, Institute of Architecture and Construction).

Main research areas: landscape architecture and planning of health resorts, planning of recreational and green areas, urban planning, land-use management, cultural heritage.

Evaldas Ramanauskas

Kaunas University of Technology, Institute of Architecture and Construction,

Centre for Territorial Planning

Address: Tunelio Str. 60, LT-44405 Kaunas, Lithuania.

Phone: 8-37-451372.

E-mail: evaldas.ramanauskas@ktu.lt

Liucijus Dringelis

Kaunas University of Technology, Institute of Architecture and Construction,

Centre for Territorial Planning

Address: Tunelio Str. 60, LT-44405 Kaunas, Lithuania.

Phone: 8-37-451372.

E-mail: liucijus.dringelis@ktu.lt 